Article

\title{
Guaianolide Sesquiterpene Lactones from Centaurothamnus maximus
}

\author{
Taha A. Hussien 1, ${ }^{\dagger}$, Tarik A. Mohamed ${ }^{2,+}{ }^{,}$Abdelsamed I. Elshamy ${ }^{3}$ (D), Mahmoud F. Moustafa ${ }^{4,5}$, \\ Hesham R. El-Seedi ${ }^{6,7,8, *}$, Paul W. Pare ${ }^{9}$ (D) and Mohamed-Elamir F. Hegazy ${ }^{2,10, *}$
}

check for

updates

Citation: Hussien, T.A.; Mohamed, T.A.; Elshamy, A.I.; Moustafa, M.F.; El-Seedi, H.R.; Pare, P.W.; Hegazy, M.-E.F. Guaianolide Sesquiterpene Lactones from Centaurothamnus maximus. Molecules 2021, 26, 2055. https://doi.org/10.3390/ molecules26072055

Academic Editors: Hosam O. Elansary and Agnieszka Szopa

Received: 27 February 2021

Accepted: 30 March 2021

Published: 3 April 2021

Publisher's Note: MDPI stays neutral with regard to jurisdictional claims in published maps and institutional affiliations.

Copyright: (c) 2021 by the authors. Licensee MDPI, Basel, Switzerland. This article is an open access article distributed under the terms and conditions of the Creative Commons Attribution (CC BY) license (https:/ / creativecommons.org/licenses/by/ $4.0 /)$.
1 Pharmacognosy Department, Faculty of Pharmacy, Sphinx University, New Assiut City, Assiut 10, Egypt; thussien71@yahoo.com

2 National Research Centre, Chemistry of Medicinal Plants Department, 33 El-Bohouth St., Dokki, Giza 12622, Egypt; ta.mourad@nrc.sci.eg

3 National Research Centre, Department of Natural Compounds Chemistry, 33 El-Bohouth St., Dokki, Giza 12622, Egypt; ai.el-shamy@nrc.sci.eg

4 Department of Biology, College of Science, King Khalid University, Abha 61421, Saudi Arabia; mfmostfa@kku.edu.sa

5 Department of Botany \& Microbiology, Faculty of Science, South Valley University, Qena 83523, Egypt

6 Department of Molecular Biosciences, The Wenner-Gren Institute, Stockholm University, S-106 91 Stockholm, Sweden

7 International Research Center for Food Nutrition and Safety, Jiangsu University, Zhenjiang 212013, China

8 Department of Chemistry, Faculty of Science, Menoufia University, Shebin El-Kom 32512, Egypt

9 Department of Chemistry \& Biochemistry, Texas Tech University, Lubbock, TX 79409, USA; paul.pare@ttu.edu

10 Department of Pharmaceutical Biology, Institute of Pharmaceutical and Biomedical Sciences, Johannes Gutenberg University, Staudinger Weg 5, 55128 Mainz, Germany

* Correspondence: hesham.elseedi@su.se (H.R.E.-S.); me.fathy@nrc.sci.eg (M.-E.F.H.); Tel.: +46-73-566-8234 (H.R.E.-S.); Tel.: +20-033-371-635 (M.-E.F.H.)

+ These authors contributed equally to this work.

Abstract: Centaurothamnus maximus (family Asteraceae), is a leafy shrub indigenous to the southwestern Arabian Peninsula. With a paucity of phytochemical data on this species, we set out to chemically characterize the plant. From the aerial parts, two newly identified guaianolides were isolated: $3 \beta$-hydroxy- $4 \alpha$ (acetoxy)- $4 \beta$ (hydroxymethyl)- $8 \alpha$-(4-hydroxy methacrylate)- $1 \alpha H, 5 \alpha H, 6 \alpha H$ gual-10(14),11(13)-dien-6,12-olide (1) and 15-descarboxy picrolide A (2). Seven previously reported compounds were also isolated: $3 \beta, 4 \alpha, 8 \alpha$-trihydroxy-4-(hydroxymethyl)- $1 \alpha H, 5 \alpha H, 6 \beta H, 7 \alpha H$ guai-10(14),11(13)-dien-6,12-olide (3), chlorohyssopifolin B (4), cynaropikrin (5), hydroxyjanerin (6), chlorojanerin (7), isorhamnetin (8), and quercetagetin-3,6-dimethyl ether-4'-O- $\beta$-D-pyranoglucoside (9). Chemical structures were elucidated using spectroscopic techniques, including High Resolution Fast Atom Bombardment Mass Spectrometry (HR-FAB-MS), $1 \mathrm{D}$ NMR; ${ }^{1} \mathrm{H},{ }^{13} \mathrm{C}$ NMR, Distortionless Enhancement by Polarization Transfer (DEPT), and 2D NMR $\left({ }^{1} \mathrm{H}_{-}{ }^{1} \mathrm{H}\right.$ COSY, HMQC, HMBC) analyses. In addition, a biosynthetic pathway for compounds 1-9 is proposed. The chemotaxonomic significance of the reported sesquiterpenoids and flavonoids considering reports from other Centaurea species is examined.

Keywords: Centaurothamnus maximus; Asteraceae; guaianolides; flavonoids; biosynthesis; chemotaxonomy

\section{Introduction}

Centaurothamnus maximus Wagentz and Dittri (Asteraceae) is a branched shrub that grows to a height of ca. $1.5 \mathrm{~m}$ [1]. Stems are densely white-tomentose with alternating leaves that are lanceolate to elliptic (2-6 cm wide by $8-15 \mathrm{~cm}$ long), silvery below and green above. Thistle-like magenta flowers $3-4 \mathrm{~cm}$ long at the end of the branches have a faint sweet scent [2]. Centaurothamnus is a monotypic genus from Centaurea and endemic 
to the mountains of the southwestern Arabian Peninsula. C. maximus (Forssk.) was first reported in 1775 from a collection from Yemen [1-3]. The genus is highly restricted in Saudi Arabia to cliffs and steep hillsides and is represented by ca. 200 species [4]. C. maximus is a paleoendemic species that presently grows in Yemen without any known traditional uses. This may be in part due to the plant's limited distribution to high mountains cliffs and slopes in Yemen [3].

Previous Centaurothamnus phytochemical studies have led to the isolation of the sesquiterpene lactones guaianolides, edusamanolides, germacranolides, and elemanolides [5-9], as well as several flavonoids [10] and acetylenes [11,12]. Reports concerning the phytoconstituents of $C$. maximus include the guaianolide sesquiterpene lactones chlorojanerin, janerin, and cynaropicrin [13], as well as an oxygenated homoditerpenoid [14] and an aliphatic ester $8^{\prime} \alpha$-hydroxy- $n$-decanyl- $n$-docosanonate [15].

In the current investigation, we describe the isolation and identification of two new guaianolide sesquiterpene lactones, $3 \beta$-hydroxy- $4 \alpha$ (acetoxy)- $4 \beta$ (hydroxymethyl)$8 \alpha$-(4-hydroxy methacrylate)- $1 \alpha H, 5 \alpha H, 6 \alpha H$-gual-10(14),11(13)-dien-6,12-olide (1) and 15descarboxy picrolide $A(2)$, as well as seven known compounds, $3 \beta, 4 \alpha, 8 \alpha$-trihydroxy4-(hydroxymethyl)-l $\alpha H, 5 \alpha H, 6 \beta H, 7 \alpha H$-guai-10(14),11(13)-dien-6,12-olide (3), chlorohyssopifolin B (4) [16], cynaropicrin (5) [17], hydroxyjanerin (6) [18], chlorojanerin (7) [19], isorhamnetin (8) [20], and quercetagetin-3,6-dimethyl ether-4'-O- $\beta$-D-pyranoglucoside (9) [21] (Figure 1). In addition, biosynthetic pathways for the secondary metabolites (1-9) and the chemotaxonomic significance of sesquiterpene lactones and flavonoids are discussed.

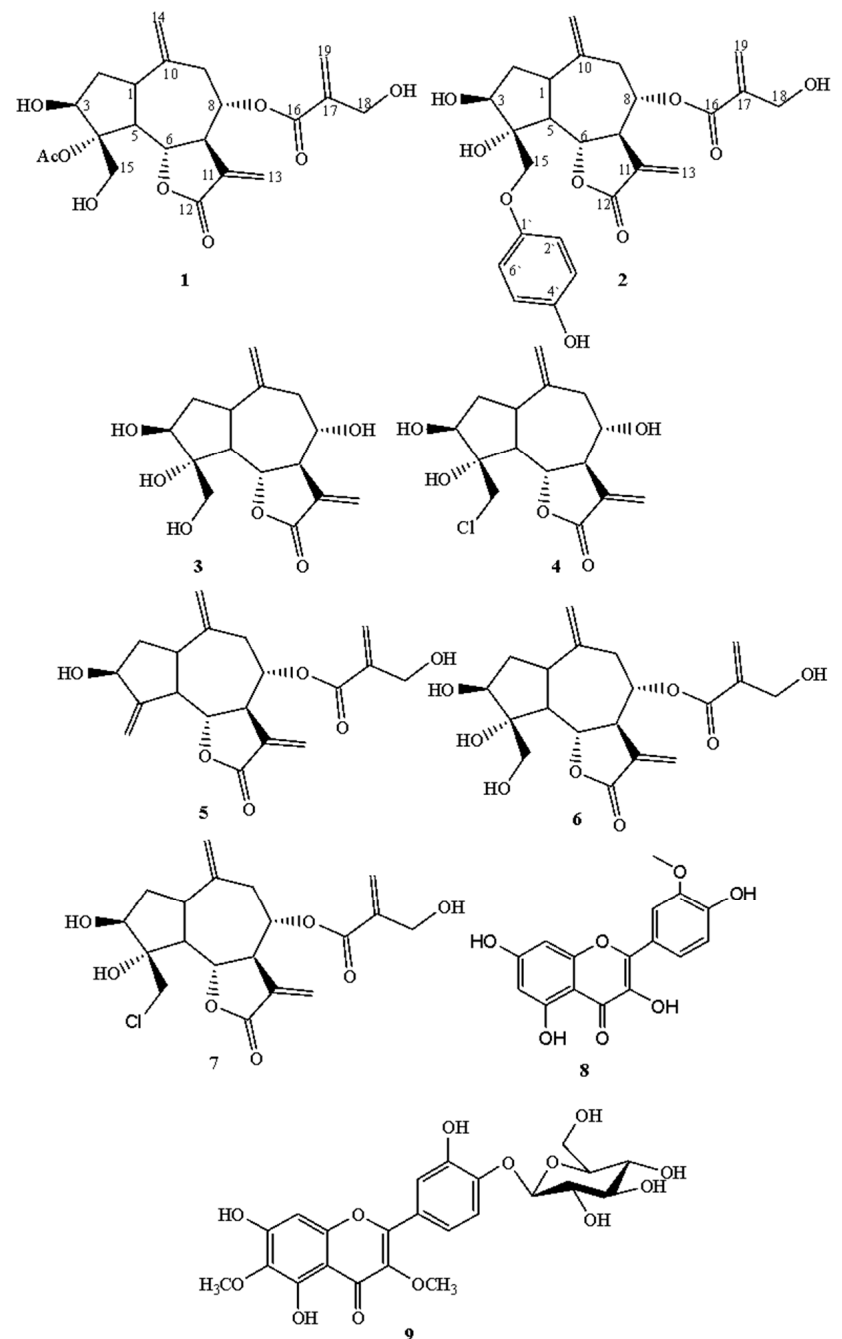

Figure 1. Structures of the isolated compounds from Centaurothamnus maximus. 


\section{Results}

\subsection{Structure Elucidation of the Isolated Compounds}

$\mathrm{A} \mathrm{CH}_{2} \mathrm{Cl}_{2}: \mathrm{MeOH}$ (1:1) of C. maximus aerial parts total extract was chromatography fractionated and purified, leading to two guaianolide sesquiterpene lactones: $3 \beta$-hydroxy$4 \alpha$ (acetoxy)- $4 \beta$ (hydroxymethyl)- $8 \alpha$-(4-hydroxy methacrylate)- $1 \alpha H, 5 \alpha H, 6 \alpha H$-gual-10(14), 11(13)-dien-6,12-olide (1) and 15-descarboxy picrolide A (2) (Figure 1).

Compound 1, a white amorphous powder, showed a molecular ion peak $[\mathrm{M}+\mathrm{H}]^{+}$ at $m / z 423.1655$ (calcd. for $\mathrm{C}_{21} \mathrm{H}_{27} \mathrm{O}_{9}, 423.1662$ ), confirmed by high-resolution FAB-MS analysis, and an optical rotation of $[\alpha] D 25=+17.0(\mathrm{c}, 0.001$, MeOH). Twenty-one carbons were detected through the ${ }^{13} \mathrm{C}$ NMR spectrum (Table 1), which was incompatible with its molecular formula. The classification of these carbons was inferred from the DEPT analyses as; one methyl, seven methylenes (three olefinic), six methines (three oxygenated at $\delta_{C} 76.1,77.1$, and 74.2), and seven quaternary carbons (three olefinic and three keto at $\delta_{C}$ 169.5, 171.9, and 156.2 (Table 1). ${ }^{1} \mathrm{H}$ NMR analysis (Table 1 ) showed a characteristic large coupling pattern of oxymethine proton at $\delta_{\mathrm{H}} 4.84\left({ }^{1} \mathrm{H}, \mathrm{t}, J_{5,6}=12.9\right)$, assigned to a lactone proton at C-6 that specified to a trans-diaxial character of the protons for C-5 $\left(\delta_{\mathrm{H}} 2.36, \mathrm{t}\right.$, $J=9.9)$ and $C-7\left(\delta_{\mathrm{H}} 3.22\right.$, brt, $\left.J=9.3\right)$, strongly suggesting a guaiane-type sesquiterpene lactone skeleton [22]. With the exception of acetoxy group at $C-4\left(\delta_{C} 83.4\right)$ and chlorine atom with up-field chemical shift of $\mathrm{C}-15\left(\delta_{\mathrm{C}} 63.4\right)$, both ${ }^{1} \mathrm{H}$ and ${ }^{13} \mathrm{C}$ NMR spectra for 1 were quite similar to those for compound 5 : ( $3 \beta, 4 \alpha$-dihydroxy- $4 \beta$-(hydroxymethyl)- $8 \alpha$-(4hydroxy-methacrylate) $1 \alpha H, 5 \alpha H, 6 \beta H, 7 \alpha H$-guai-10(14),11(14)-dien-6,12-olide), which has been previously isolated from Amberboa ramosa [16].

Table 1. ${ }^{1} \mathrm{H}$ and ${ }^{13} \mathrm{C}$ NMR data of compounds $1-7$ in $\mathrm{CDCl}_{3}(500$ and $125 \mathrm{MHz} \delta$ in ppm, $\mathrm{J}$ in $\mathrm{Hz}$ ).

\begin{tabular}{|c|c|c|c|c|c|c|c|c|c|}
\hline \multirow{2}{*}{ No. } & \multicolumn{2}{|c|}{1} & \multicolumn{2}{|c|}{2} & \multirow{2}{*}{$\begin{array}{c}3 \\
\delta_{\mathrm{C}}\end{array}$} & \multirow{2}{*}{$\begin{array}{c}4 \\
\delta_{\mathrm{C}}\end{array}$} & \multirow{2}{*}{$\begin{array}{c}5 \\
\delta_{\mathrm{C}}\end{array}$} & \multirow{2}{*}{$\begin{array}{c}6 \\
\delta_{\mathrm{C}}\end{array}$} & \multirow{2}{*}{$\begin{array}{c}7 \\
\delta_{\mathrm{C}}\end{array}$} \\
\hline & $\delta_{\mathrm{H}}$ & $\delta_{\mathrm{C}}$ & $\delta_{\mathrm{H}}$ & $\delta_{\mathrm{C}}$ & & & & & \\
\hline 1 & $3.52 \mathrm{~m}^{*}$ & 46.4 & $3.60 \mathrm{~m}^{*}$ & 46.3 & 43.4 & 47.1 & 44.8 & 44.5 & 46.1 \\
\hline 2 & $\begin{array}{l}1.60 \mathrm{~m}^{*} \\
2.35 \mathrm{~m} \text { * }\end{array}$ & 38.3 & $1.60 \mathrm{~m}^{*}$ & 39.8 & 43.3 & 38.6 & 38.6 & 37.6 & 38.6 \\
\hline 3 & $\begin{array}{c}4.05 \mathrm{dd}(7.5 \\
5.7)\end{array}$ & 76.1 & $4.16 \mathrm{~m}^{*}$ & 76.1 & 77.5 & 75.6 & 72.8 & 77.0 & 75.6 \\
\hline 4 & - & 83.4 & - & 83.8 & 83.1 & 84.4 & 152.6 & 83.9 & 84.5 \\
\hline 5 & 2.36 t (9.9) & 57.1 & $\begin{array}{c}2.45 \mathrm{dd} \\
(17.2,6.5)\end{array}$ & 57.3 & 55.1 & 58.4 & 50.7 & 55.6 & 58.3 \\
\hline 6 & $4.84 \mathrm{t}(12.9)$ & 77.1 & $4.90(21.5)$ & 77.2 & 77.8 & 77.5 & 78.9 & 77.4 & 77.1 \\
\hline 7 & $\begin{array}{c}3.22 \mathrm{brt} \\
(9.3)\end{array}$ & 48.2 & $3.35 \mathrm{~m}^{*}$ & 47.3 & 51.2 & 49.2 & 48.2 & 47.4 & 47.8 \\
\hline 8 & $\begin{array}{c}5.15 \text { ddd } \\
(10.5,4.2 \\
2.0)\end{array}$ & 74.2 & $5.16 \mathrm{~m}$ & 74.2 & 71.9 & 71.1 & 74.3 & 74.4 & 74.1 \\
\hline 9 & $\begin{array}{c}2.75 \mathrm{dd} \\
(13.5,5.9) \\
2.42 \mathrm{~m}\end{array}$ & 35.0 & $\begin{array}{c}2.76 \mathrm{dd}(7.5 \\
6.9), 2.39 \\
\mathrm{dd} \\
(12.9,10.7)\end{array}$ & 38.4 & 36.5 & 38.6 & 36.3 & 37.0 & 34.4 \\
\hline 10 & - & 143.0 & - & 143.5 & 142.8 & 143.8 & 142.6 & 142.1 & 143.6 \\
\hline 11 & - & 138.0 & - & 140.6 & 137.3 & 139.0 & 138.3 & 136.8 & 138.0 \\
\hline 12 & - & 169.5 & - & 165.2 & 170.2 & 170.2 & 169.9 & 169.9 & 169.5 \\
\hline 13 & $\begin{array}{c}6.10 \mathrm{~d}(3.8) \\
5.60 \mathrm{~d} \\
(3.24)\end{array}$ & 120.8 & $\begin{array}{l}5.66 \mathrm{~d}(4.1) \\
6.12 \mathrm{~d}(4.1)\end{array}$ & 121.5 & 124.1 & 121.2 & 121.1 & 123.3 & 120.8 \\
\hline 14 & $\begin{array}{l}5.14 \text { brs, } \\
4.82 \text { brs }\end{array}$ & 116.5 & $\begin{array}{c}5.1 \text { brs, } 4.75 \\
\text { brs }\end{array}$ & 117.0 & 116.1 & 115.5 & 116.8 & 117.4 & 116.1 \\
\hline
\end{tabular}


Table 1. Cont.

\begin{tabular}{|c|c|c|c|c|c|c|c|c|c|}
\hline \multirow{2}{*}{ No. } & \multicolumn{2}{|c|}{1} & \multicolumn{2}{|c|}{2} & \multirow{2}{*}{$\begin{array}{c}3 \\
\delta_{\mathrm{C}}\end{array}$} & \multirow{2}{*}{$\begin{array}{c}4 \\
\delta_{\mathrm{C}}\end{array}$} & \multirow{2}{*}{$\begin{array}{c}5 \\
\delta_{\mathrm{C}}\end{array}$} & \multirow{2}{*}{$\begin{array}{c}6 \\
\delta_{\mathrm{C}}\end{array}$} & \multirow{2}{*}{$\begin{array}{c}7 \\
\delta_{\mathrm{C}}\end{array}$} \\
\hline & $\delta_{\mathrm{H}}$ & $\delta_{\mathrm{C}}$ & $\delta_{\mathbf{H}}$ & $\delta_{\mathrm{C}}$ & & & & & \\
\hline 15 & $\begin{array}{l}4.50 \mathrm{~d} \\
(12.0)\end{array}$ & 66.5 & $\begin{array}{l}4.59 \mathrm{~d} \\
(13.9)\end{array}$ & 66.2 & 63.6 & 48.7 & 111.5 & 63.4 & 48.7 \\
\hline 16 & - & 165.2 & $\begin{array}{c}3.4 \text { brs, } 2.41 \\
\text { brs }\end{array}$ & 169.5 & & & 165.17 & 165.5 & 165.2 \\
\hline 17 & - & 140.6 & $\begin{array}{l}5.99 \mathrm{~d}(3.6), \\
6.33 \mathrm{~d}(3.6)\end{array}$ & 138.1 & - & - & 140.5 & 139.7 & 140.6 \\
\hline 18 & $4.33 \mathrm{brs}$ & 60.2 & $4.33 \mathrm{~s}$ & 60.2 & - & - & 60.3 & 61.4 & 60.2 \\
\hline 19 & $\begin{array}{l}6.32 \text { brs, } \\
5.99 \text { brs }\end{array}$ & 124.5 & - & 124.5 & - & - & 124.6 & 126.3 & 124.5 \\
\hline $1^{\prime}$ & - & & - & 138.1 & - & - & - & - & - \\
\hline $2^{\prime}$ & - & & $\begin{array}{l}6.85 \mathrm{~d} \\
(10.5)\end{array}$ & 114.6 & - & - & - & - & - \\
\hline $3^{\prime}$ & - & & $\begin{array}{l}8.00 \mathrm{~d} \\
(10.5)\end{array}$ & 131.7 & - & - & - & - & - \\
\hline $4^{\prime}$ & - & & - & 124.5 & - & - & - & - & - \\
\hline $5^{\prime}$ & - & & $\begin{array}{l}8.00 \mathrm{~d} \\
(10.5)\end{array}$ & 131.7 & - & - & - & - & - \\
\hline $6^{\prime}$ & - & & $\begin{array}{l}6.85 \mathrm{~d} \\
(10.5)\end{array}$ & 114.6 & - & - & - & - & - \\
\hline $\mathrm{C}=\mathrm{O}, \mathrm{OAc}$ & - & 171.9 & - & - & - & - & - & - & - \\
\hline $\mathrm{CH} 3, \mathrm{OAc}$ & $2.11 \mathrm{~s}$ & 19.5 & - & - & - & - & - & - & - \\
\hline
\end{tabular}

The appearance of a sharp singlet signal at $\delta_{\mathrm{H}} 2.11(3 \mathrm{H}, \mathrm{s}, \mathrm{H}-1)$ together with new ester carbonyl at $\delta_{C} 171.9$ in $\mathbf{1}$, along with an absence of these signals in 5, indicates the presence of an acetoxy group instead of hydroxyl group at C-4. While it is possible that such an acetate functionality is a chemical artifact (e.g., drying and/or extraction), the fact that such derivatizations have been phytochemically studied in the same manner from the same genus and other genera suggests that these natural products are in fact plant-derived metabolites.

Two-dimensional NMR data $\left({ }^{1} \mathrm{H}^{-}{ }^{1} \mathrm{H}\right.$ COSY, HMQC and HMBC) clearly indicate that the acetoxy of $\mathbf{1}$ is comparable to that of 5 [16]. HMBC correlations (Figure 2) were observed between $\mathrm{H}-8 / \mathrm{C}-16$ and $\mathrm{H}-18 / \mathrm{C}-16, \mathrm{C}-17$, and $\mathrm{C}-19$, supporting the sequence and position of the side chain at $\mathrm{C}-8$. In addition to two- and three-bond correlations between $\mathrm{H}-1 / \mathrm{C}-3$, C-6, C-7, C-10; H-2/C-3, C-4, C-5, C-6, C-10, C-14; H-5/C-1, C-2; H-6/C-1, C-8; H-7/C-1; $\mathrm{H}-14 / \mathrm{C}-1, \mathrm{C}-8, \mathrm{C}-9$; and $\mathrm{H}-8 / \mathrm{C}-6, \mathrm{C}-14$ were further confirmation of the structure of 1 (Figure 2).

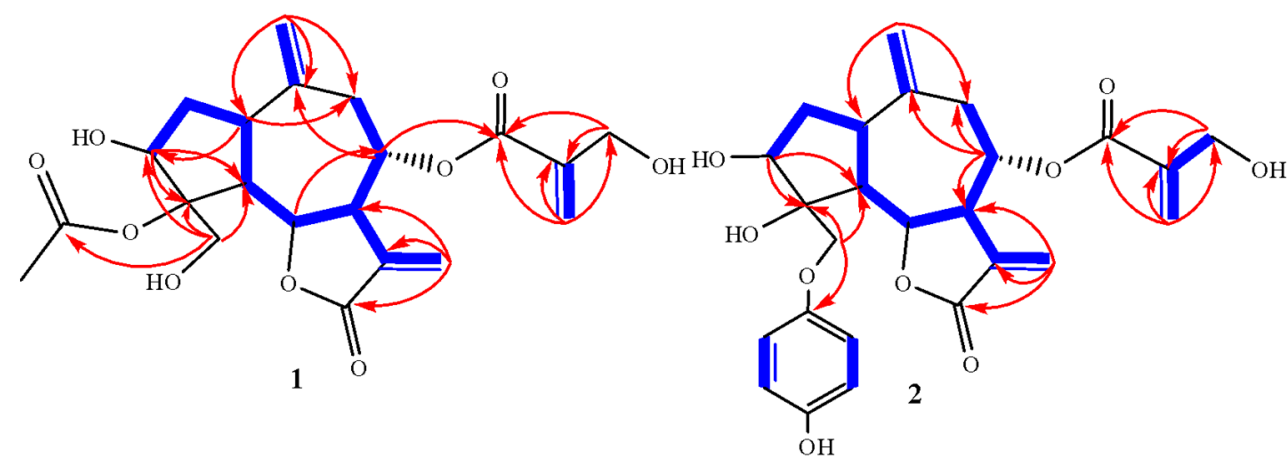

Figure 2. Observed ${ }^{1} \mathrm{H}-{ }^{1} \mathrm{H}-\mathrm{COSY}$ (bold blue line) and $\mathrm{HMBC}$ (red arrow) correlations for $\mathbf{1}$ and 2. 
The relative stereochemistry of $\mathbf{1}$ was determined by comparison of the coupling constants and the biogenetic correlation with the corresponding guaianolides isolated from other Asteraceae species [23,24]. NOESY correlations (Figure 3) between H-1, H-3, $\mathrm{H}-5$, and $\mathrm{H}-9$ are in an $\alpha$ orientation, and NOESY correlations between $\mathrm{H}-6, \mathrm{H}-8$, and H-15 are in a $\beta$ orientation. From the spectral data reported here, 1 was identified as $3 \beta-$ hydroxy- $4 \alpha$ (acetyloxy)-4 $\beta$ (hydroxymethyl)- $8 \alpha$-(4-hydroxy methacrylate)- $1 \alpha H, 5 \alpha H, 6 \alpha H$ gual-10(14),11(13)-dien-6,12-olide, a newly reported natural product.
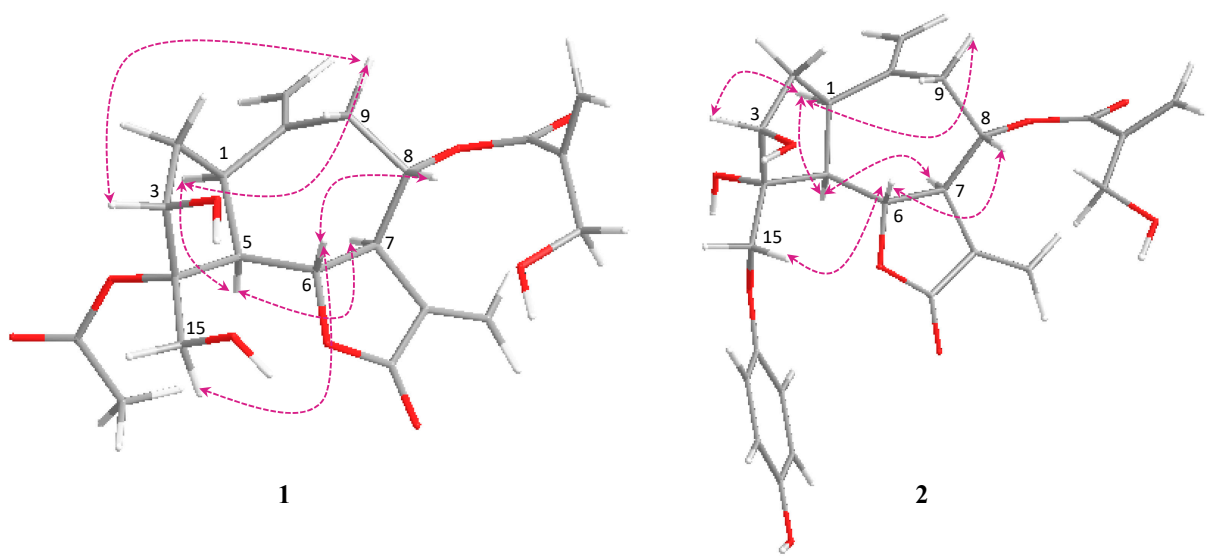

Figure 3. Significant NOESY correlations of 1 and 2.

Compound 2, a yellowish amorphous powder, had an optical rotation of $[\alpha] D 25=$ +7.0 (c, 0.005, MeOH). A base peak at $m / z 472.1758$ [M] corresponded to a molecular formula of $\mathrm{C}_{25} \mathrm{H}_{28} \mathrm{O}_{9}$ (calcd. for $\mathrm{C}_{25} \mathrm{H}_{28} \mathrm{O}_{9}, 472.2042$ ) in the HR-FAB-MS spectrum. ${ }^{13} \mathrm{C}$ NMR and DEPT spectral analyses (Table 1) revealed 25 carbons that were classified as seven methylenes (three olefinic), 10 methines (three oxygenated at $\delta_{C} 76.1,77.2$, and 74.2), and eight quaternary carbons (three olefinic as well as two keto at $\delta_{C} 165.5(\mathrm{C}-12)$ and 169.5 (C-16), (Table 1). ${ }^{1} \mathrm{H}$ NMR spectral data (Table 1) show characteristic resonances for ap-disubstituted benzene moiety at $\delta_{\mathrm{H}}\left(2 \mathrm{H}, J=10.5, \mathrm{H}-2^{\prime}, 6^{\prime}\right)$ and $6.85(2 \mathrm{H}, J=2.4$, $\left.\mathrm{H}-3^{\prime}, 5^{\prime}\right)$. Aromatic carbons were observed at $\delta_{\mathrm{C}} 138.1,114.6,131.7$, and 124.5 , confirming $p$-disubstituted aromatic moiety. Proton signals were similar to a previously reported picrolide A isolated from Acroptilon repens [25]. Signal alternations included an ester carbonyl carbon for picrolide A reported at $\delta_{C}$ 167.1, which was missing in 2, suggesting that the aromatic ring attached at C-15 and present as $p$-dihydroxy benzene moiety in 2 was modified to a $p$-hydroxy benzoate moiety in picrolide A. The HMBC connections (Figure 2) from $\mathrm{H}-15$ to $\mathrm{C}-1^{\prime} / \mathrm{C}-3 / \mathrm{C}-4$; $\mathrm{H}-2^{\prime}, 6^{\prime}$ to $\mathrm{C}-3^{\prime} / \mathrm{C}-4^{\prime} / \mathrm{C}-5^{\prime}$; and $\mathrm{H}-3^{\prime}, 4^{\prime}$ to $\mathrm{C}-1^{\prime} / 2^{\prime} / 6^{\prime}$ further confirmed the structure and location of the aromatic moiety at $\mathrm{C}-15$. Three correlations were also observed from H-8 to C-16, H-18 to C-16/C-17, and H-19 to C-16/C-17/C-18, supporting the sequence and position of the side chain at $\mathrm{C}-8$. In addition, two- and threebond correlations from $\mathrm{H}-1$ to $\mathrm{C}-3 / \mathrm{C}-6 / \mathrm{C}-7 / \mathrm{C}-10, \mathrm{H}-2$ to $\mathrm{C}-3 / \mathrm{C}-4 / \mathrm{C}-5 / \mathrm{C}-6 / \mathrm{C}-10 / \mathrm{C}-14$, H-5 to C-1/C-2, H-6 to C-1/C-8, H-7 to C-1, H-14 to C-1/C-8/C-9, and H-8 to C-6/C-14 were further confirmation of the structure of 2 (Figure 2).

The relative configurations of both $\mathbf{1}$ and $\mathbf{2}$ were the same when compared with the corresponding guaianolides isolated from Asteraceae $[23,24]$. NOESY correlations (Figure 3) between H-1, H-3, H-5, and H-9 are in an $\alpha$ orientation, and NOESY correlations between $\mathrm{H}-6, \mathrm{H}-8$, and $\mathrm{H}-15$ are in a $\beta$ orientation. Accordingly, the structure of 2 was established as a new derivative of picrolide $A$ and named 15-descarboxy picrolide A.

\subsection{Proposed Biosynthetic Pathway of the Isolated Compounds}

Generally, the terpenoids biosynthesis in plants can arise in dissimilar subcellular compartments, the cytosol, mitochondria, and/or plastids [26,27]. Biosynthetically, farnesyl diphosphate (FPP) is considered the main precursor for biosynthesis of a vast array of 
sesquiterpene. Cyclization of FPP into (+) germacrene A is catalyzed by $(+)$ germacrene A synthase (GAS) [28]. The latter is converted to the corresponding acid, germacrene A acid, through hydroxylation and oxidation reactions catalyzed by cytochrome $\mathrm{P}_{450}$ germacrene A oxidase (GAO). Germacrene A acid is then hydroxylated at C-6 to produce 6-hydroxygermacrene $\mathrm{A}$ acid as an unstable intermediate by the action of another cytochrome $\mathrm{P}_{450}(+)$ costunolide synthase (COS). Costunolide is obtained from this intermediate that undergoes spontaneous non-enzymatic lactonization of the hydroxyl group at C-6 with the carboxylic group at C-12 (Figure 4) [29-31]. Costunolide is considered a branching point precursor for producing germacranolides, eudesmanolides, and guaianolides as the three major sesquiterpene lactones groups. Thus, 4,5 epoxidation of costunoilde is hypothesized to be the first committed step in guaianolide biosynthesis through the conversion of costunolide to parthenolidecatalyzed by parthenolide synthase (TpPTS) [31]. The opening of the epoxide through an intramolecular attack of the double bond generates the three-cyclic skeleton as a guaianolide-type intermediate that is responsible for generating a large variety of guaianolides (Figure 4) [29,32,33]. The guaianolides in Asteraceae have a specific biosynthetic pathway with unique conformations that differ from guaianolides in the family Apiaceae. The lactone ring in Apiaceae is either $6 \beta, 8 \alpha$ or $6 \beta, 8 \beta$, whereas in Asteraceae, it has only been seen as $6 \alpha, 8 \beta[23,24]$. The hydroxylase enzymes activate an enzymatic hydroxylation of the guaianolide-type intermediate at C-3, C-8, and C15 , thereby producing compound 3 . Compound 4 was biosynthetically proposed by incorporation of chloride atoms at C-15 of compound 3, which catalyzed by Flavin adenine dinucleotide $\left(\mathrm{FADH}_{2}\right)$-dependent halogenases as the type of halogenating enzymes of compounds activated for electrophilic attack (Figure 4). On the other hand, the C-8 position is easily hydroxylated by the enzyme CYP71BL1 and acts as an active site to accept acyloxy moiety via the $\mathrm{P}_{450}$ acetyltransferase enzyme [34]. The generation of the side chain at C-8 is proposed via esterification of the hydroxyl group at C-8 with acrylic moiety, followed by methylation and hydroxylation of the side chain to generate compound 6 . The latter is considered the main precursor of compounds $1,2,5$, and 4 through specific biochemical pathways (Figure 4). Compound 7 is similar to 4 in chlorination of 6 at C-15, which is activated by FADH2-dependent halogenases. The acetylation of 6 at C-4 is believed to be mediated by an acetyl transferase, which catalyzes the transfer of an acetyl group from acetyl-CoA as a donor molecule to produce an acetylated analogue 1. Compound 2, however, may be obtained via condensation reaction of compound $\mathbf{6}$ at C-15 with a simple aromatic moiety, such as hydroquinone, which may be produced from shikimic acid as precursor. The dehydrogenase enzyme may be converting the primary alcoholic group at $\mathrm{C}-15$ in compound 6 into a formyl group that also converted into a methyl one by reductase enzyme, and a double bond between C-4 and C-15 is formed by losing one molecule of water to produce compound 5 (Figure 4).

Flavonoids are products of a shikimic acid and the acetate pathway by condensation of 4-hydroxy cinnamoyl-coenzyme A, referred to as 4-coumaroyl coenzyme A, with unit 9 of malonyl coenzyme A. The plant utilizes a shikimic acid pathway for deriving a polyketide intermediate that forms a chalcone skeleton. The chalcone skeleton serves as a key intermediate in the biosynthesis of several classes of flavonoids [35-37]. The proposed biosynthetic pathway of compounds $\mathbf{8}$ and $\mathbf{9}$ is shown in Figure 5.

\subsection{Chemosystematic Significance}

Centaurothamnus is a monotypic genus that is a cross-taxon basionym with the genus Centaurea. The genus Centaurea is considered an attractive source for sesquiterpene lactones and flavonoids [38,39]. The Centaurea species are rich in various types of sesquiterpene lactones, including guaianolides, germacranolide, eudesmanolides, and elemanolides. The guaianolides are the most abundant and more distributed in genus Centaurea $[40,41]$. Based on bibliographic research, about 54 guaianolide sesquiterpene compounds have been isolated from 80 Centaurea species, as well as 20 germacronolides from 46 species, 7 elemanolides from 10 species and 4 eudesmanolides from 3 species [42]. There are 
also review articles that describe sesquiterpene lactones isolated from specific Centaurea species, including 20 guaianolides isolated from C. acaulis, C. omphalotricha, and C. musimomum; 11 germacranolides and 12 elemanolides from C. acaulis, C. melitensis, C. calictrapa, C. foucauldiana, C. lippii, C. parviflora, C. tougourensis, C. sulphurea, C. papposa, C. sicula, and C.pullata; and 8 eudesmanolides from C. acaulis, C. papposa, C. granata, C. pullata and C. maroccana [43]. In addition, guaianolides and elemanolides have been isolated from Centaurea, including four guaianolides and cynaratriol from C. musimomum [44]; centaurpensin and 13-acetyl solstitian A from C. solstitialis [45]; cebellin M from C. bella [46]; the elemanolideshierapolitanins A, B, C, and D isolated from C. hierapolitana [22]; and $13-N$-proline melitensin and $13-N$-proline- $6 \alpha, 8 \alpha, 15$-trihydroxy elema-1,3-diene-oic acid from C. polyclada [47].

Chlorinated guaianolides with noted medical value have been isolated from species of Centaurea [48]. The chlorinated guaianolide derivatives were reported as chlorohyssopifolins A and C, which were isolated from C. bella, C. carthelinica, C. aegyptiaca, C. colchica, C. dealbata, C. exsurgens, C. hyssopifolia, C. janeri, C. karabaghensis, C. somchetica, C. taochia, and C. zangezuri [49]; chlorohyssopifolin B reported from C. aegyptiaca, C. Hyssopifolia [49], and C. linifolia [50]; chlorohyssopifolins D and E from C. hyssopifolia [51] and C. linifolia [50]; chlorojanerinfrom C. aegyptica [52], C. hyssopifolia [53] and C. sinaica [54]; chlororepdiolide from C. repens; 19-desoxychlorojanerin from C. aegyptiaca [48]; elegin from C. repens [55] and C. solistitialis [56]; epi-centaurepensin, episolistiolide, and linichlorin A from C. linifolia [49]; solistitiolide from $C$. repens and C. solistitialis [56]; 14-chloro-10- $\beta$ hydroxy-10(14)-dihydrozaluzanin D from C. acaulis [57]; and cebellin C and centaurepensin from C. bella [58].

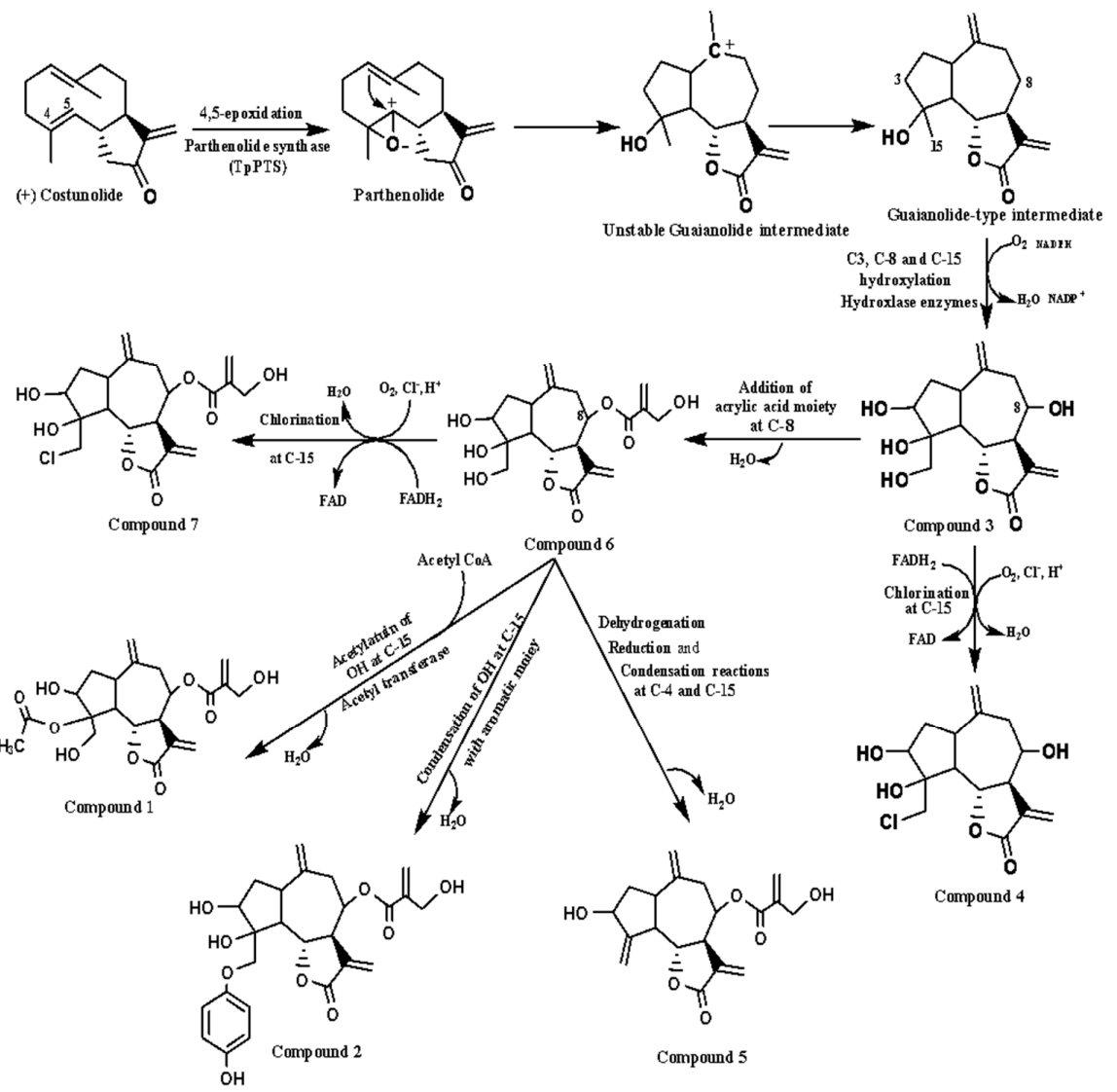

Figure 4. Biosynthesis proposed pathway scheme for the isolated guaianolides. 


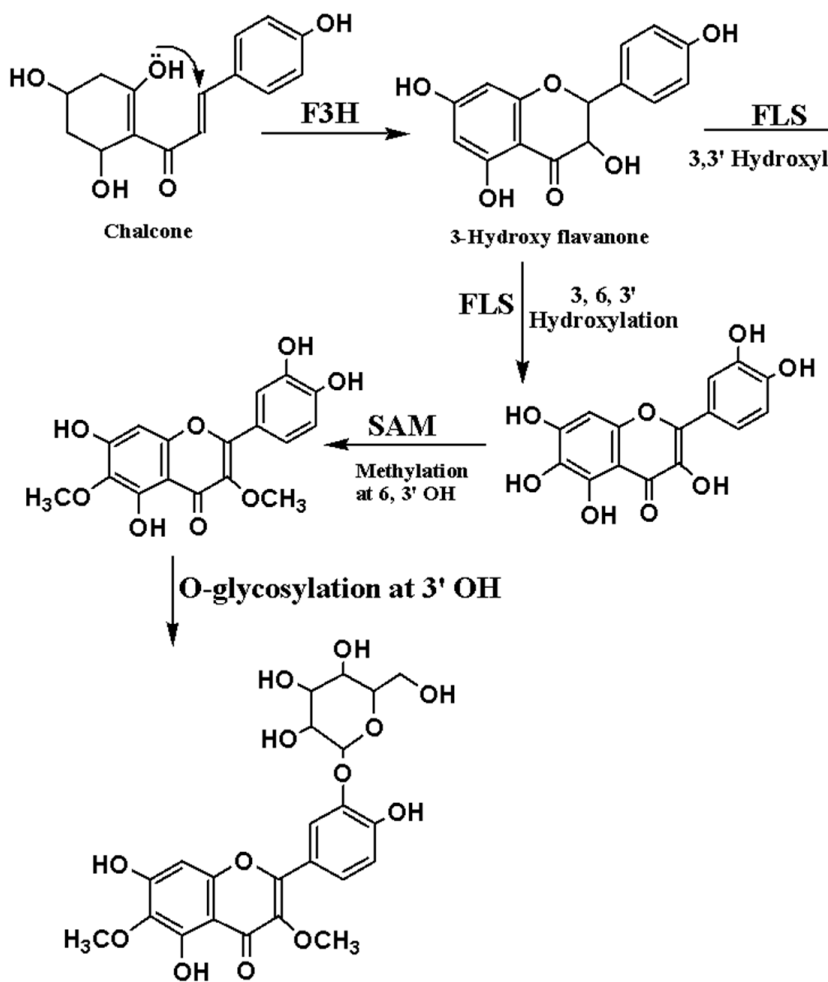

Compound 3<smiles></smiles><smiles>COc1cc(-c2oc3cc(O)cc(O)c3c(=O)c2O)ccc1O</smiles>

Compound 9

Figure 5. Proposed biosynthesis pathway scheme for the isolated methoxyled flavones.

On the other hand, flavonoids are also distributed in different species of Centaurea. Different reports showed that 119 flavonoids of various types, primarily belonging to the flavone class, have been isolated from 53 Centaurea species. Apigenin and luteolin, as well as their glycosides, were the most common flavones in the Centaurea species. The glycosylation of flavones was commonly found at position 7 as 6-methoxykaempferol 7-O-glucoside, kaempferol 7-O-glucoside, along with hispidulin-7-O-glucoside from $C$. macrocarpa [59], apigenin $4^{\prime}-\left(6^{\prime}\right.$-methylglucuronide) from C. nicaeensis [60], and apigetrin from $C$. resupinate [61]. The flavonol glycosides derivatives were rare; only patuletin-7-Oglucoside was isolated from C. macrocarpa [59] and nicotiflorin as a flavonol-3-O-glucoside from C. resupinate [61].

The methoxylated flavone derivatives were commonly detected in genus Centaurea as 6-mono-methoxyflavones, which are represented as 6-methoxykaempferol and 6methoxyluteoin from C. macrocarpa [59], 5,7-dihydroxy-6-methoxyflavone (oroxylin A), and 5,7,4'-trihydroxy-6-methoxyflavone (hispidulin) from C. ragusina [62]. Other rare methoxylated flavone derivatives include $3^{\prime}$-mono-methoxyflavones, such as chrysoeriol from $C$. resupinate [61] and 6,5'-dimethoxyflavones such as jaceosidin from $C$. nicaeensis [60]. 6,7,3'-Trimethoxyflavone was found as cirsilineol from $C$. nicaeensis [60]. The 5,7-dihydroxyflavone derivative chrysin was reported from both C. ragusina [62] and C. resupinata [61], and the 5,7, 4'-trihydroxyflavone derivative apigenin was isolated from $C$. resupinate [61]. Prunasin, a cynogenic glycoside, was observed in C. nicaeensis [60].

In the present study, seven guaianolide sesquiterpene, including two chlorinated guaianolides, namely chlorohyssopifolin B (4) [16] and chlorojanerin (7) [19], together with two flavonoid compounds, 5,7,4'-trihydroxy-3,6-dimethoxyflavone-4'-O-glucoside (9) and isorhamnetin (8) (Litvinenko and Bubenchikova, 1988), were isolated from C. maximus. Compound $\mathbf{3}$ was firstly isolated from genus Centaurea and previously characterized from Amberboaramosa [16]. Chlorohyssopifolin B (4) was also previously reported from Amberboaramosa [16], C. aegyptiaca [48], C. maximus, C. hyssopifolia, and C. linifolia [49]; 5 was previously isolated from C. amberboa, C. dealbata, C. exarate [49], C. linifolia, and C. maximus [63]; 
6 was firstly isolated from Centaurea and previously isolated from Amberboaramosa [16] and Cousiniaaitchisonii [18]; and 7 (chlorojanerin) was previously reported from C. adjarica [64], C. Janeri [53], C. sinaica [54], and C. Aegyptiaca [48]. Compounds $\mathbf{1}$ and $\mathbf{2}$ were isolated and characterized as new guaianolides from $C$. maximus. The $3^{\prime}$ methoxyflavonol derivative 8 was first characterized from C. maximus and previously isolated from C. kotschyi [65], C. cynaus [20], and C. aegyptiaca [66], whereas 5,7,4'-trihydroxy-3,6-dimethoxyflavone-3'-Oglucoside (9) was isolated as a new natural compound from C. maximus [21].

Based on the above studies, it appears that guaianolide sesquiterpene lactones isolated from C. maximus are similar to those reported from C. aegyptiaca, and C. linifolia, which have overlapping biosynthetic pathways and are characterized by their potential to produce chlorinated guaianolides as well as methoxylated flavonoid derivatives.

\section{Materials and Methods}

\subsection{General Procedures}

Optical rotations were recorded on a JASCO P-2300 polarimeter (Jasco Corporation, Tokyo, Japan). NMR and HR-MS spectra were recorded on a Bruker 500 NMR (Bruker, Billerica, MA, USA) and JEOL JMS-700 (JEOL, Ltd., Tokyo, Japan) instrument, respectively. A JASCO 810 spectropolarimeter was used for circular dichroism.

Chromatographic separation was applied using semi-preparative Agilent 1200 High performance liquid chromatography (HPLC) with a refractive index (RI) detector (Santa Clara, CA, USA) and reversed-phase column chromatography (YMC-Pack ${ }^{\mathrm{TM}}$ octadecylsilyl (ODS) column $(250 \times 10 \mathrm{~mm}, 5 \mu \mathrm{m})$, Marcon Boulevard, Allentown, PA, USA). Silica gel 60 (Merck, 230-400 mesh; Merck, Darmstadt, Germany) and precoated RP-18 $\mathrm{F}_{254}$ plates (Merck, Darmstadt, Germany) were used for column chromatography and Thin Layer Chromatography (TLC) analysis, respectively.

\subsection{Plant Material}

The wild aerial parts of C. maximus were collected in March 2015 from Al Udayn, Ibb, Yemen. The plant was kindly identified by Prof. Dr. Abdulnaser Al Gifri of the Biology Department at Education College, Aden University, Yemen. A voucher specimen (P 610) was deposited in the Pharmacy Department at the University of Sciences and Technology, Ibb, Yemen.

\subsection{Extraction and Isolation}

The air-dried powder of $C$. maximus $(1 \mathrm{~kg})$ was extracted using methylene chloridemethanol $(1: 1 ; v / v, 4 \mathrm{~L})$ at room temperature. A gummy residue $(90.5 \mathrm{~g})$ extract was produced via in vacuo concentration, followed by fractionation on silica gel flash column chromatography using $n$-hexane ( $3 \mathrm{~L}, 100 \%)$ and then by gradient of $n$-hexane/ethyl acetate up to $100 \%$ ethyl acetate and ethyl acetate-methanol up to $15 \% \mathrm{MeOH}$ ( $2 \mathrm{~L}$ of each solvent mixture). Twelve major fractions were collected together based on the TLC profile. Vanillinsulfuric acid reagent was used for the detection of compound spots to yield the following six fractions: A (10.0 g), B (6.0 g), C (11.5 g), D (15.0 g), E (13.0 g), and F (7.5 g). Fraction C was subjected to further fractionation on the ODS column $(3 \times 60 \mathrm{~cm})$; the eluted gradient with Elution started with 100\% water, and the polarity was decreased with $10 \%$ increments of methanol until reaching $100 \%$. The subfractions were obtained and subjected to isolation and purification by RP-18 HPLC $(20 \times 250 \mathrm{~cm})$ using $80: 20 \% \mathrm{MeOH}: \mathrm{H}_{2} \mathrm{O},(8: 1,2.5 \mathrm{~L})$ to produce compound $5(20.0 \mathrm{mg})$ and $\mathbf{6}(15.0 \mathrm{mg})$. Fraction $\mathrm{D}$ was also subjected to further fractionation on the ODS column $(3 \times 60 \mathrm{~cm})$ using $80: 20 \%\left(\mathrm{MeOH}: \mathrm{H}_{2} \mathrm{O}\right)$ and finally eluted with $100 \% \mathrm{MeOH}$. The obtained fractions were further purified by RP-18 HPLC using $\mathrm{MeOH}: \mathrm{H}_{2} \mathrm{O}(7: 2,2.5 \mathrm{~L})$ with a flow rate of $5 \mathrm{~mL} / \mathrm{min}$ to obtain $\mathbf{1}(11.5 \mathrm{mg}), 2(13.5 \mathrm{mg})$, and $9(10 \mathrm{mg})$. Fraction E was purified by RP-18 HPLC using $\mathrm{MeOH}(6: 3,2.5 \mathrm{~L})$ with a flowrate of $6 \mathrm{~mL} / \mathrm{min}$ to produce $3(7.5 \mathrm{mg})$ and $4(12 \mathrm{mg})$. Fraction F was purified by RP-18 HPLC using $\mathrm{MeOH}: \mathrm{H}_{2} \mathrm{O}(50: 50 \%, 2.5 \mathrm{~L})$ with a flowrate of $5 \mathrm{~mL} / \mathrm{min}$ to afford $7(9.5 \mathrm{mg})$ and 8 
(15.0 mg). NMR assignments for isolated secondary metabolites (1-9) were included in the Supplementary Materials: S1-S28.

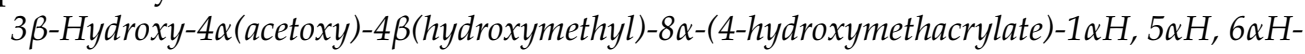
gual-10(14), 11(13)-dien-6,12-olide (1). Amorphous powder; $[\alpha] D 25=+17.0$ (c, 0.001, $\mathrm{MeOH})$; ${ }^{1} \mathrm{H}\left(\mathrm{CDCl}_{3}, 500 \mathrm{MHz}\right)$ and ${ }^{13} \mathrm{C}\left(\mathrm{CDCl}_{3}, 125 \mathrm{MHz}\right)$ NMR; see Table 1 . FAB-MS $m / z=423.1655$ $[\mathrm{M}+\mathrm{H}]^{+}$; HR-FAB-MS $m / z=423.1655$ (calcd. for $\mathrm{C}_{21} \mathrm{H}_{27} \mathrm{O}_{9}, 423.2222$ ).

15-Descarboxy picrolide A (2). Amorphous powder; $[\alpha] D 25=+7.0(c, 0.005, \mathrm{MeOH}) ;{ }^{1} \mathrm{H}$ $\left(\mathrm{CDCl}_{3}, 500 \mathrm{MHz}\right)$ and ${ }^{13} \mathrm{C}\left(\mathrm{CDCl}_{3}, 125 \mathrm{MHz}\right) \mathrm{NMR}$; see Table 1 . FAB-MS $m / z=472.1758$ $[\mathrm{M}]^{+}$; HR-FAB-MS $m / z=472.1758$ (calcd. for $\mathrm{C}_{25} \mathrm{H}_{28} \mathrm{O}_{9}, 472.2042$ ).

\section{Conclusions}

Two new guaianolide sesquiterpene lactones (1-2) were characterized from C. maximus, as well as five known guaianolide sesquiterpene (3-7), including two chlorinated guaianolides (4 and 7), together with two known flavonoids (8-9). Compounds 3, 6 and 9 were firstly isolated from genus Centaurothamnus, while, 4 and $\mathbf{8}$ were isolated for the first time from C. maximus. Biosynthetically, costunolide is considered the branching point precursor for producing germacranolides, eudesmanolides, and guaianolides, however, 4,5 epoxidation of costunoilde is hypothesized to be the first committed step in the Asteraceae family for guaianolide biosynthesis through the conversion of costunolide to parthenolide. By opening of the epoxide through an intramolecular attack of the double bond, the threecyclic skeleton is generated as a guaianolide type intermediate and can go on to generate a variety of enzymatically mediated guaianolides. Guaianolide biosynthesized in the family Asteraceae have a specific biosynthetic pathway with the lactone ring having a $6 \alpha, 8 \beta$ conformation. Based on chemosystematic analysis, guaianolide sesquiterpenes from $C$. maximus exhibit chemical overlap with Centaurea aegyptiaca, and C. linifolia, confirming their placement in one section. Additional data on guaianolide sesquiterpenes and flavonoids from other Centaurea species will be required to further elucidate intergeneric relationships.

Supplementary Materials: The following are available online, Figures S1-S28: NMR spectra for compounds 1-9.

Author Contributions: Conceptualization, T.A.H., T.A.M. and M.-E.F.H.; formal analysis, T.A.M. and A.I.E.; investigation, T.A.H., T.A.M. and A.I.E.; writing—original draft preparation, T.A.H., M.F.M., P.W.P. and M.-E.F.H.; writing-review and editing, M.F.M., H.R.E.-S., P.W.P. and M.-E.F.H.; funding acquisition, M.F.M. and H.R.E.-S. All authors have read and agreed to the published version of the manuscript.

Funding: M.F. Moustafa thank the Deanship of Scientific Research at King Khalid University, Kingdom of Saudi Arabia for funding (R.G.P.1/143/42). H.R. El-Seedi is very grateful to the Swedish Research links Grant VR 2016-05885 and the Department of Molecular Biosciences, Wenner-Grens Institute, Stockholm University, Sweden, for the financial support. M.-E.F. Hegazy gratefully acknowledges the financial support from Alexander von Humboldt Foundation "Georg Foster Research Fellowship for Experienced Researchers".

Institutional Review Board Statement: Not applicable.

Informed Consent Statement: Not applicable.

Data Availability Statement: The data presented in this study are available in Supplementary Materials.

Conflicts of Interest: The authors declare no conflict of interest.

Sample Availability: Samples of the compounds 3, 6 and 7 are available from the authors.

\section{References}

1. Collenette, S. Wild Flowers of Saudi Arabia; The National Commission for Wildlife Conversation and Development (NCWCD): Riyadh, Saudi Arabia, 1999.

2. Ghazal, E.M.A.A. Taxonomic studies on the family asteraceae (Compositae) of Hajjah governorate, West of Yemen. J. Med. Plants Stud. 2019, 7, 90-100.

3. Wood, J.R. A Handbook of the Yemen Flora; Royal Botanic Gardens, Kew: London, UK, 1997. 
4. Basahi, M.A.; Thomas, J.; Al-Turki ${ }^{\circ}$, T.A.; Alfarhan, A.H.; Al-Atar, A.A.; Sivadasan, M. Current status and conservation efforts of cevt4. Uroth, 4 mvus maximus wagenitz. S. Ditt rich. Plant Arch. 2010, 10, 807-814.

5. Oksuz, S.; Topcu, G. Guaianolides from Centaurea-Glastifolia. Phytochemistry 1994, 37, 487-490. [CrossRef]

6. Youssef, D.; Frahm, A.W. Constituents of the Egyptian Centaurea scoparia; Part II. Guaianolides of the aerial parts. Planta Med. 1994, 60, 572-575. [CrossRef]

7. Barrero, A.F.; Sanchez, J.F.; Rodrı'guez, I. Germacranolides from Centaurea melitensis. Phytochemistry 1989, $28,1975-1976$. [CrossRef]

8. Wang, Y.H.M.; Cheng, C.H.K.; Costall, B.; Naylor, R.J.; Jenner, P.; Hostettmann, K. Neurotoxic Sesquiterpenoids from the Yellow Star Thistle Centaurea solstitialis L. (Asteraceae). Helv. Chim. Acta 1991, 74, 117-123. [CrossRef]

9. Tortajada, A.; Picher, M.T.; Reventos, M.M.; Amigo, J.M. Structure and Stereochemistry of Melitensin, an Elemanolide from Centaurea-Aspera Var Stenophylla. Phytochemistry 1988, 27, 3549-3550. [CrossRef]

10. Bensouici, C.; Kabouche, A.; Kabouche, Z.; Touzani, R.; Bruneau, C. Sesquiterpene lactones and flavonoids from Centaurea foucauldiana. Chem. Nat. Compd. 2012, 48, 510-511. [CrossRef]

11. Bohlmann, F. Naturally Occurring Acetylenes. Acad. Press N. Y. 1973, 452-460.

12. Stevens, K.L.; Wong, R.Y. Structure of chlororepdiolide, a new sesquiterpene lactone from Centaurea repens. J. Nat. Prod. 1986, 49, 833-837. [CrossRef]

13. Muhammad, W.; Takamatsu, S.; Mossa, J.S.; El-Feraly, F.S.; Walker, L.A.; Clark, A.M. Cytotoxic sesquiterpene lactones from Centaurothamnus maximus and Vicoa pentanema. Phytother. Res. 2003, 17, 168-173. [CrossRef] [PubMed]

14. Alam, P.; Al-Anezi, M.; Siddiqui, N.A.; Alajmi, M.F.; Al-Rehaily, A.J.; Haque, A.; Ali, M. Isolation and characterization of a new oxygenated homoditerpenoid from leaves of Centaurothamnus maximus with antimicrobial potential. Pak. J. Pharm. Sci. 2015, 28, 1091-1095. [PubMed]

15. Siddiqui, N.A.; Al Anezi, M.A.; Alam, P.; Haque, A.; Basodan, O.A.; Ali, M.J. Isolation of New Aliphatic Ester 8'[alpha]-Hydroxyn-decanyl n-docosanoate from the Leaves of Centaurothamnus maximus Wagentz and Dittri. Asian J. Chem. 2015, $27,2651$. [CrossRef]

16. Khan, S.B.; Azhar-ul-Haq; Perveen, S.; Afza, N.; Malik, A.; Nawaz, S.A.; Shah, M.R.; Choudhary, M.I. Butyrylcholinesterase inhibitory guaianolides from Amberboa ramosa. Arch. Pharm. Res. 2005, 28, 172-176. [CrossRef]

17. Rial, C.; Novaes, P.; Varela, R.M.; Molinillo, J.M.; Macias, F.A. Phytotoxicity of cardoon (Cynara cardunculus) allelochemicals on standard target species and weeds. J. Agric. Food Chem. 2014, 62, 6699-6706. [CrossRef] [PubMed]

18. Iranshahy, M.; Tayarani-Najaran, Z.; Kasaian, J.; Ghandadi, M.; Emami, S.A.; Asili, J.; Chandran, J.N.; Schneider, B.; Iranshahi, M. Highly Oxygenated Sesquiterpene Lactones from Cousinia aitchisonii and their Cytotoxic Properties: Rhaserolide Induces Apoptosis in Human T Lymphocyte (Jurkat) Cells via the Activation of c-Jun n-terminal Kinase Phosphorylation. Phytother. Res. 2016, 30, 222-226. [CrossRef]

19. Saklani, A.; Hegde, B.; Mishra, P.; Singh, R.; Mendon, M.; Chakrabarty, D.; Kamath, D.V.; Lobo, A.; Mishra, P.D.; Dagia, N.M.; et al. NF-кB dependent anti-inflammatory activity of chlorojanerin isolated from Saussurea heteromalla. Phytomed. Int. J. Phytother. Phytopharm. 2012, 19, 988-997. [CrossRef] [PubMed]

20. Litvinenko, V.I.; Bubenchikova, V.N. Phytochemical Study of Centaurea-Cyanus. Khim. Prir. Soedin+ 1988, 24, 672-674. [CrossRef]

21. Hua, Y.; Wang, H.Q. Studies on the flavonoids from whole herbs of Seriphidium terrae-albae. Zhongguo Zhong Yao Za Zhi 2006, 31, 820-822.

22. Karamenderes, C.; Bedir, E.; Pawar, R.; Baykan, S.; Khan, K.A. Elemanolide sesquiterpenes and eudesmane sesquiterpene glycosides from Centaurea hierapolitana. Phytochemistry 2007, 68, 609-615. [CrossRef]

23. Holub, M.; Budesinsky, M. On Terpenes 292. Sesquiterpene Lactones of the Umbelliferae. Phytochemistry 1986, $25,2015-2026$. [CrossRef]

24. Azarken, R.; Guerra, F.M.; Moreno-Dorado, F.J.; Jorge, Z.D.; Massanet, G.M. Substituent effects in the transannular cyclizations of germacranes. Synthesis of 6-epi-costunolide and five natural steiractinolides. Tetrahedron 2008, 64, 10896-10905. [CrossRef]

25. Stevens, K.L.; Witt, S.C.; Kint, S.; Haddon, W.F.; Benson, M. Picrolide-a-An Unusual Sesquiterpene Lactone from AcroptilonRepens. J. Nat. Prod. 1991, 54, 276-280. [CrossRef]

26. Gutensohn, M.N.D.; Dudareva, N. Involvement of compartmentalization in monoterpene and sesquiterpene biosynthesis in plants. In Isoprenoid Synthesis in Plants and Microorganisms; Bach, T.J., Rohmer, M., Eds.; Springer: New York, NY, USA, 2013; pp. 155-169.

27. Lange, B.M.; Ahkami, A. Metabolic engineering of plant monoterpenes, sesquiterpenes and diterpenes-current status and future opportunities. Plant Biotechnol. J. 2013, 11, 169-196. [CrossRef]

28. Bouwmeester, H.J.; Kodde, J.; Verstappen, F.W.; Altug, I.G.; de Kraker, J.W.; Wallaart, T.E. Isolation and characterization of two germacrene A synthase cDNA clones from chicory. Plant Physiol. 2002, 129, 134-144. [CrossRef]

29. De Kraker, J.W.; Franssen, M.C.; Joerink, M.; de Groot, A.; Bouwmeester, H.J. Biosynthesis of costunolide, dihydrocostunolide, and leucodin. Demonstration of cytochrome p450-catalyzed formation of the lactone ring present in sesquiterpene lactones of chicory. Plant Physiol. 2002, 129, 257-268. [CrossRef]

30. Ikezawa, N.; Gopfert, J.C.; Nguyen, D.T.; Kim, S.U.; O’Maille, P.E.; Spring, O.; Ro, D.K. Lettuce costunolide synthase (CYP71BL2) and its homolog (CYP71BL1) from sunflower catalyze distinct regio- and stereoselective hydroxylations in sesquiterpene lactone metabolism. J. Biol. Chem. 2011, 286, 21601-21611. [CrossRef] 
31. Liu, Q.; Majdi, M.; Cankar, K.; Goedbloed, M.; Charnikhova, T.; Verstappen, F.W.A.; de Vos, R.C.H.; Beekwilder, J.; van der Krol, S.; Bouwmeester, H.J. Reconstitution of the Costunolide Biosynthetic Pathway in Yeast and Nicotiana benthamiana. PLoS ONE 2011, 6. [CrossRef]

32. Piet, D.P.; Schrijvers, R.; Franssen, M.C.R.; Degroot, A. Biotransformation of Germacrane Epoxides by Cichorium-Intybus. Tetrahedron 1995, 51, 6303-6314. [CrossRef]

33. Dewick, P.M. The biosynthesis of C5-C20 terpenoid compounds. Nat. Prod. Rep. 1995, 12, 507-534. [CrossRef] [PubMed]

34. Chang, M.C.; Keasling, J.D. Production of isoprenoid pharmaceuticals by engineered microbes. Nat. Chem. Biol. 2006, $2,674-681$. [CrossRef] [PubMed]

35. Watson, R.R. Vegetables Fruits And Herbs In Health Promotion, 1st ed.; CRC Press: London, UK, 2001; Volume 7, pp. 140-141.

36. Rangari, V.D. Pharmacognosy \& Phytochemistry, 1st ed.; part-1; Carrier Publication: Nashik, India, 2008 ; Volume 171, p. 242.

37. Cordell, G.A. Medicinal Natural Products: A Biosynthetic Approach; By PM Dewick (University of Nottingham); John Wiley and Sons, Ltd.: Oxford, UK; ACS Publications: Washington, DC, USA, 2002; Volume x1i 507, pp. 18-24. ISBN 0-471-49640-5. x1i+507 $18.5 \times 24.5 \mathrm{~cm} .115 .00(72.95$ paperback).

38. Ferreres, F.; Tomas, F.; Guirado, A.; Tomas, F.A. Flavonoid aglycones in centaura-aspera (compositae). Afinidad 1980, 37, 337-338.

39. Gadeschi, E.; Jorge, Z.; Massanet, G.; Luis, F.J.P. Two derivatives of costic acid from Centaurea arguta. Phytochemistry 1989, 28, 2204-2206. [CrossRef]

40. Saroglou, V.; Karioti, A.; Demetzos, C.; Dimas, K.; Skaltsa, H. Sesquiterpene lactones from Centaurea spinosa and their antibacterial and cytotoxic activities. J. Nat. Prod. 2005, 68, 1404-1407. [CrossRef]

41. Shakeri, A.; Amini, E.; Asili, J.; Masullo, M.; Piacente, S.; Iranshahi, M. Screening of several biological activities induced by different sesquiterpene lactones isolated from Centaurea behen L. and Rhaponticum repens (L.) Hidalgo. Nat. Prod. Res. 2018, 32, 1436-1440. [CrossRef]

42. Al Easa, H.S.; Rizk, A.M. Constituents of Centaurea species. Phytochemistry 1992, 12, $27-57$.

43. Ayad, R.; Akkal, S. Phytochemistry and biological activities of algerian Centaurea and related genera. In Studies in Natural Products Chemistry; Elsevier: Amsterdam, The Netherlands, 2019; Volume 63, pp. 357-414.

44. Lopez-Rodriguez, M.; Garcia, V.P.; Zater, H.; Benayache, S.; Benayache, F. Cynaratriol, a sesquiterpene lactone from Centaurea musimomum. Acta Cryst. E 2009, 65, o1867-o1868. [CrossRef]

45. Ozcelik, B.; Gurbuz, I.; Karaoglu, T.; Yesilada, E. Antiviral and antimicrobial activities of three sesquiterpene lactones from Centaurea solstitialis L. ssp solstitialis. Microbiol. Res. 2009, 164, 545-552. [CrossRef] [PubMed]

46. Nowak, G.D.-P.R.; Urbanska, M.; Nawrot, J. TLC of selected sesquiterpenoids of the Asteraceae family. Acta Soc. Bot. Pol. 2011, 80, 193-196. [CrossRef]

47. Demir, S.; Karaalp, C.; Bedir, E. Specialized metabolites from the aerial parts of Centaurea polyclada DC. Phytochemistry 2017, 143, 12-18. [CrossRef]

48. Eldahmy, S.; Bohlmann, F.; Sarg, T.M.; Ateya, A.; Farrag, N. New Guaianolides from Centaurea aegyptica. Planta Med. 1985, 51, 176-177.

49. Nowak, G.; Drożdż, B.; Kroszczyński, W.; Holub, M. Sesquiterpene lactones. XXX. Cynaropicrin in species of the subtribe Centaureanae Dumort. Acta Soc. Bot. Pol. 1986, 55, 17-22. [CrossRef]

50. González, A.G.; Bermejo, J.; Amaro, J.M.; Massanet, G.M.; Galindo, A.; Cabrera, I. Sesquiterpene lactones from Centaurea linifolia Vahl. Can. J. Chem. 1978, 56, 491-494. [CrossRef]

51. Gonzalez, A.G.; Bermejo, J.; Breton, J.L.; Massanet, G.M.; Triana, J. Chlorohyssopifolin C, D, E and vahlenin, four new sesquiterpene lactones from Centaurea hyssopifolia. Phytochemistry 1974, 13, 1193-1197. [CrossRef]

52. Gonzalez, A.G.; Bermejo, J.; Breton, J.L.; Massanet, G.M.; Dominguez, B.; Amaro, J.M. The chemistry of the compositae. Part XXXI. Absolute configuration of the sesquiterpene lactones centaurepensin (chlorohyssopifolin A), acroptilin (chlorohyssopifolin C), and repin. J. Chem. Soc. Perkin Trans. 1 1976, 15, 1663-1666. [CrossRef]

53. Gonzalez, A.G.; Bermejo, J.; Massanet, G.M. Aportacion al estudio quimiotaxonomico del genero Centaurea. Rev. Lat. Quim 1977, 8, 176-181.

54. Sarg, T.; el-Dahmy, S.; el-Domiaty, M.; Ateya, A. Guaianolides and other constituents from Centaurea sinaica. Acta Pharm. Hung. 1988, 58, 129-133. [PubMed]

55. Stevens, K.L. Sesquiterpene lactones from Centaurea repens. Phytochemistry 1982, 21, 1093-1098. [CrossRef]

56. Stevens, K.L.M.G. The Chemistry of Alieopathy. 1984, 84-98.

57. Bentamène, A.; Benayache, S.; Crèche, J.; Petit, G.; Bermejo-Barrera, J.; Leon, F.; Benayache, F. New guaianolide and other sesquiterpene lactones from Centaurea acaulis L.(Asteraceae). Biochem. Syst. Ecol. 2005, 33, 1061-1065. [CrossRef]

58. Xu, C.C.; Wang, B.; Pu, Y.Q.; Tao, J.S.; Zhang, T. Advances in extraction and analysis of phenolic compounds from plant materials. Chin. J. Nat. Med. 2017, 15, 721-731. [CrossRef]

59. Louaar, S.; Achouri, A.; Lefahal, M.; Laouer, H.; Medjroubi, K.; Duddeck, H.; Akkal, S. Flavonoids from Algerian Endemic Centaurea microcarpa and their Chemotaxonomical Significance. Nat. Prod. Commun. 2011, 6, 1603-1604. [CrossRef]

60. Hammoud, L.; Seghiri, R.; Benayache, S.; Mosset, P.; Lobstein, A.; Chaabi, M.; Leon, F.; Brouard, I.; Bermejo, J.; Benayache, F. A new flavonoid and other constituents from Centaurea nicaeensis All. var. walliana M. Nat. Prod. Res. 2012, 26, 203-208. [CrossRef]

61. Bouzghaia, B.; Moussa, M.T.B.; Goudjil, R.; Harkat, H.; Pale, P. Chemical composition, in vitro antioxidant and antibacterial activities of Centaurea resupinata subsp. dufourii (dostal) greuter. Nat. Prod. Res. 2020, 1-6. [CrossRef] [PubMed] 
62. Grienke, U.; Radic Brkanac, S.; Vujcic, V.; Urban, E.; Ivankovic, S.; Stojkovic, R.; Rollinger, J.M.; Kralj, J.; Brozovic, A.; Radic Stojkovic, M. Biological Activity of Flavonoids and Rare Sesquiterpene Lactones Isolated From Centaurea ragusina L. Front. Pharm. 2018, 9, 972. [CrossRef]

63. González, A.G.; Arteaga, J.M.; Bretón, J.L. Germacranolides from Centaurea seridis. Phytochemistry 1973, 12, 2997-2999. [CrossRef]

64. Nowak, G.; Holub, M.; Buděšĺnský, M. Sesquiterpene lactones. XXXVI. Sesquiterpene lactones in several subgenera of the genus Centaurea, L. Acta Soc. Bot. Pol. 1989, 58, 95-102. [CrossRef]

65. Oksuz, S.; Putun, E. Flavonoids of Centaurea kotschyi var Kotschyi. Doga Turk Kim. Derg 1987, 11, 66-71.

66. Bakr, R.O.; Mohamed, S.; Ayoub, N. Phenolic profile of Centaurea aegyptiaca l. growing in egypt and its cytotoxic and antiviral activities. Afr. J. Tradit. Complementary Altern. Med. Ajtcam 2016, 13, 135-143. [CrossRef] [PubMed] 